http://nv.nltu.edu.ua

https://doi.org/10.15421/40290708

@ Correspondence author

Article received 09.09.2019 p.

Article accepted 26.09.2019 p.

A. V. Kodzhebash

Удк 712.4(477.44)

anastasiia.vadumivna@gmail.com

А. В. Коджебаш

Уманський національний університет садівництва, м. Умань, Україна

\title{
ПРОПОЗИЦІЇ ЩОДО РЕКОНСТРУКЦІЇ ПАРКУ СЕЛА ПІКІВЕЦЬ УМАНСЬКОГО РАЙОНУ
}

Парк у с. Піківець Уманського району Черкаської області було закладено у 50-60-х роках XX ст. у центрі села, а саме біля сільського клубу. Насамперед потрібно провести санітарне рубання та обрізування дерев. Пропонуємо підсіяти мавританський газон, а в місці, де зростає пирій повзучий (Elytrigia repens L.), повністю замінити травостій на газон. Згідно 3 проектом розширюється стежкова мережа. Запропоновано створення доріжок з бетонної тротуарної плитки завширшки 0,75 та 1,5 м. Деякі стежки виконуватимуть транзитну роль, а деякі сполучатимуть окремі елементи парку. 3 малих архітектурних форм у парку встановлюємо альтанку для відпочинку. Також запропоновано збільшити кількість лавок, додавши дугоподібну лавку на круглому майданчику, у центрі якого розміщуватиметься клумба. Позаду кругової лавки, у північно-східній частині парку запроектовано створення декоративної групи з кущів. Асортимент рослин для цієї групи включає: Berberis thunbergii DC, Forsythia europaea Deg. et Bald., Pyracantha coccinea (L.) M. Roem, Syringa vulgaris L., Cotoneaster horizontalis Decne. Для клумб використовуємо цибулькові ранньоквітучі види, а також переважно тіньовитривалі багаторічники. Рекомендуємо створити мавританський газон, до складу якого входять: костриця червона (Festuca rubra L.), райграс пасовищний (Lolium perenne L.), тонконіг лучний (Poa pratensis L.), мак польовий (Papaver rhoeas L.), льон великоквітковий (Linum grandiflorum Desf.), ромашка лікарська (Matricaria recutita L.), низькорослі сорти космеї (Cosmos Cav.), чорнобривці мексиканські (Tagetes tenuifolia Cav.), гіпсофіла повзуча (Gypsophila muralis L.), гіпсофіла витончена (Gypsophila elegans M. Bieb.).

Ключові слова: газон; клумба; санітарне обрізування; стежкова мережа; альтанка.

Вступ. Найбільш актуальним завданням на шляху модернізації сільського парку $\epsilon$ реалізація сучасних проектів і програм, направлених на розвиток комунікації об'єктів соціальної сфери із залученням до цього процесу громадських об'єднань, бізнес-структур тощо, а також активізація громади до ведення активного способу життя, зміцнення здоров'я, покращення екологічної ситуації в селі.

Основна проблема таких парків полягає в тому, що вони є занедбаними, тобто вимагаю повної реконструкції та благоустрою. Такі парки потрібно розбудувати з використанням сучасних передових ідей ландшафтного дизайну на підставі наявного зеленого масиву із використанням усіх особливостей ландшафту. У відновленому парку мають бути створені усі умови для відпочинку різних вікових категорій відвідувачів: розташовані ігрові розважальні комплекси, атракціони, спортивні майданчики, місця культурного дозвілля. Організацію паркового простору потрібно проводити 3 використанням сучасних інженерних гідросистем та освітлення.

Мета дослідження - розробити проект реконструкції парку села Піківець.

Матеріали та методика дослідження. Назви рослини подано за В. Я. Заячуком (Zaiachuk, 2008), а також за визначником рослин (Dobrochaeva et al., 1987), латинські назви уточнено за міжнародною класифікацією The Plant Database. Креслення розроблено за допомогою комп'ютерної програми Kompas 3D 14. Візуалізацію окремих елементів виконано за допомогою програми PhotoShop.

Основні результати дослідження. Парк у с. Піківець
Уманського р-ну Черкаської обл. було закладено в 5060-х роках ХХ ст. у центрі села, а саме біля сільського клубу. Його площа становить 0,89 га. Парк доглянутий, проте потребує реконструкції та оптимізації насаджень (Dobrochaeva et al., 1987). Наявну планувальну структуру можна побачити на план-схемі території парку (рис. 1).

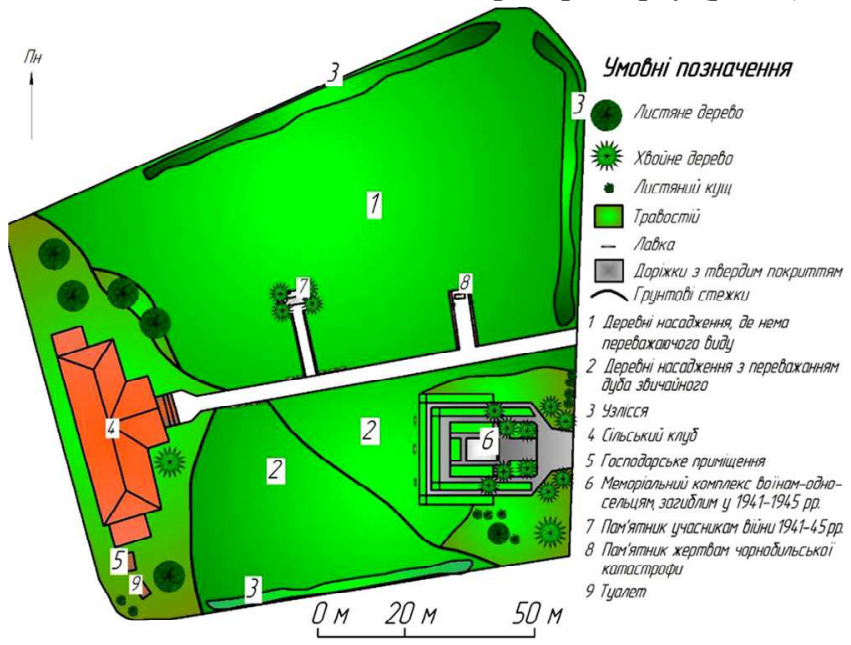

Рис. 1. План-схема території парку села Піківець: 1) деревні насадження без переважаючого виду; 2) деревні насадження з переважанням дуба звичайного; 3) узлісся; 4) сільський клуб 3 бібліотекою; 5) господарське приміщення; 6) меморіальний комплекс загиблим у 1941-1945 pр. воїнам-односельцям; 7) пам'ятник учасникам війни 1941-1945 pp.; 8) пам'ятник жертвам Чорнобильської трагедії; 9) туалет

Інформація про авторів:

Коджебаш Анастасія Вадимівна, аспірантка, кафедра лісового господарства. Email: anastasiia.vadumivna@gmail.com Цитування за ДСтУ: Коджебаш А. В. Пропозиції щодо реконструкції парку села Піківець Уманського району. Науковий вісник НЛту України. 2019, т. 29, № 7. С. 38-41.

Citation APA: Kodzhebash, A. V. (2019). Reconstruction Proposals for the Village Park Pikovets, Uman District. Scientific Bulletin of UNFU, 29(7), 38-41. https://doi.org/10.15421/40290708 
Насамперед потрібно провести санітарне рубання та обрізування дерев. У меморіальному комплексі на братській могилі є самосів шовковиці білої (Morus alba L.), який необхідно видалити. Також потрібно викорчувати шипшину собачу (Rosa canina L.), що зростає куртиною та знижує естетичний вигляд насадження парку.

Трав'яний покрив неоднорідний, за типами газонних трав не диференціюється, має досить низький естетичний вигляд. Пропонуємо підсіяти мавританський газон, а в місці, де зростає пирій повзучий (Elytrigia repens L.), повністю замінити травостій на газон. Газон пропонуємо озеленити таким складом трав і квітів: костриця червона (Festuca rubra L.), райграс пасовищний (Lolium perenne L.), тонконіг лучний (Poa pratensis L.), мак польовий (Papaver rhoeas L.), льон великоквіковий ( $\mathrm{Li}$ num grandiflorum Desf.), ромашка лікарська (Matricaria recutita L.), низькорослі сорти космеї (Cosmos Cav.), чорнобривці мексиканські (Tagetes tenuifolia Cav.), гіпсофіла повзуча (Gypsophila muralis L.), гіпсофіла витончена (Gypsophila elegans M. Bieb.).
Авторський проект реконструкції наведено на рис. 2.

Згідно $з$ проектом розширюється стежкова мережа. Запропоновано створення доріжок з бетонної тротуарної плитки завширшки 0,75 та 1,5 м. Деякі доріжки виконуватимуть транзитну роль, а деякі сполучатимуть окремі елементи парку.

3 малих архітектурних форм у парку встановлюємо альтанку для відпочинку, також запропоновано збільшити кількість лавок, додавши дугоподібну лавку в круглому майданчику, у якому в центрі розміщуватиметься клумба. Лавки, що розміщені рядком позаду меморіального комплексу, рекомендуємо перенести. Доцільно збільшити й кількість урн для сміття, оскільки зростає кількість місць відпочинку. Біля ходів, що ведуть до сільського клубу, пропонуємо встановити симетрично дві бетонні вази, в які щорічно висаджувати пеларгонію (Pelargōnium L'Her.).

Позаду кругової лавки, у північно-східній частині парку запроектовано створення декоративної групи 3 кущів (рис. 3). Асортимент рослин для цієї композиції зі зазначенням необхідної кількості наведено у табл. 1.

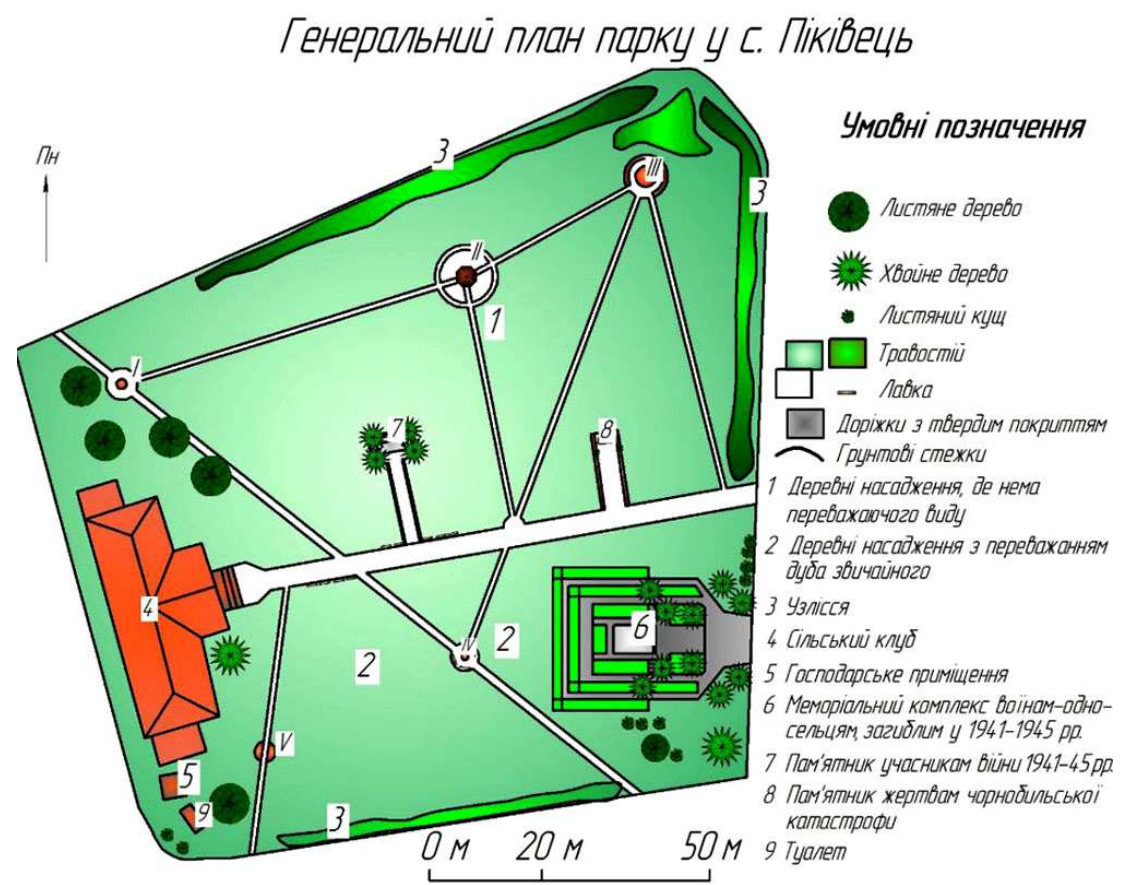

Рис. 2. Генеральний план парку с. Піківець: 1) деревні насадження без переважаючого виду; 2) деревні насадження 3 переважанням дуба звичайного; 3) узлісся; 4) сільський клуб з бібліотекою; 5) господарське приміщення; 6) меморіальний комплекс загиблим у 1941-1945 рр. воїнам-односельцям; 7) пам'ятник учасникам війни 1941-1945рр.; 8) пам'ятник жертвам Чорнобильської трагедії; 9) туалет

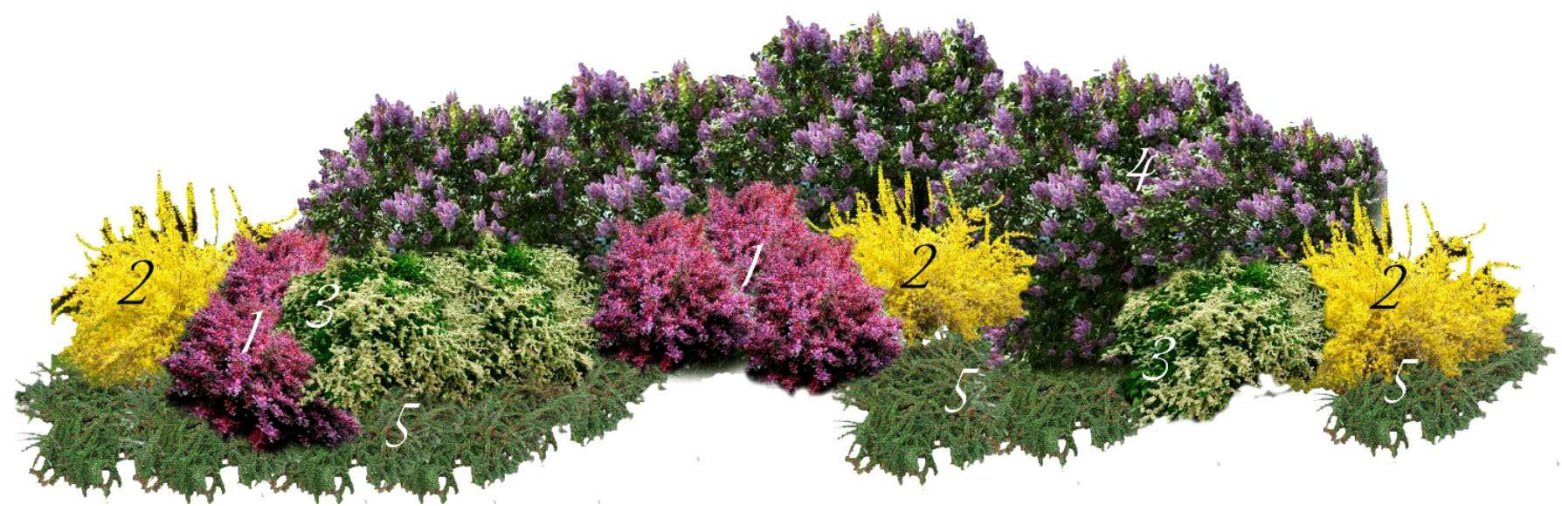

Рис. 3. Група з декоративних кущів (загальний вигляд: 1) барбарис Тунберга пурпуролистий (Berberis thunbergii DC); 2) форзиція європейська (Forsythia europaea Deg. et Bald.); 3) піраканта яскраво-червона (Pyracantha coccinea (L.) M. Roem); 4) бузок звичайний (Syringa vulgaris L.); 5) кизильник горизонтальний (Cotoneaster horizontalis Decne.) 
Табл. 1. Асортимент рослин декоративної групи

\begin{tabular}{|c|c|c|c|c|}
\hline$№$ 3/п & Українська назва & Латинська назва & Період квітування & К-ть, шт. \\
\hline 1 & Барбарис Тунберга пурпуролистий & Berberis thunbergii DC & Травень & 5 \\
\hline 2 & Форзиція європейська & Forsythia europaea Deg. et Bald. & Квітень & 3 \\
\hline 3 & Піраканта яскраво-червона & Pyracantha coccinea (L.) M. Roem & Травень-червень & 3 \\
\hline 4 & Бузок звичайний & Syringa vulgaris L. & Травень-червень & 5 \\
\hline 5 & Кизильник горизонтальний & Cotoneaster horizontalis Decne. & Травень-липень & 15 \\
\hline
\end{tabular}

У піраканти оранжево-червоні плоди дозрівають у вересні та часто залишаються на кущі до весни, що сприяє високому рівню декоративності майже цілий рік. У барбарису плоди достигають у вересні-жовтні, а потім довго залишаються на кущі. Плоди кизильника яскраво-червоні, блискучі, достигають у вересні і зберігаються на гілках до грудня, а на гілках, що в нижній частині куща - висять до весни. Таке довге зберігання ягід на кущах забезпечать декоративність композиції не тільки у період квітування, а й після. Для клумб використовуємо цибулькові ранньоквітучі види, а також переважно тіньовитривалі багаторічники (табл. 2).

Табл. 2. Асортимент рослин для квітників

\begin{tabular}{|c|c|c|c|}
\hline $\begin{array}{l}\text { № } \\
3 / \Pi\end{array}$ & Українська назва & Латинська назва & $\begin{array}{l}\text { К- } \\
\text { сть, } \\
\text { шт. }\end{array}$ \\
\hline \multicolumn{4}{|c|}{ Квітник I } \\
\hline 1 & Хоста гібридна & Hosta hybrida var. Altanis & 1 \\
\hline 2 & $\begin{array}{l}\text { Хоста подорожни- } \\
\text { кова }\end{array}$ & Hosta plantaginea (Lam.) Asch. & 6 \\
\hline 3 & Хоста ланцетолиста & Hosta lancifolia (Thunb.) Engl. & 25 \\
\hline 4 & Нарцис білий & Narcissus poeticus L. & 45 \\
\hline \multicolumn{4}{|c|}{ Квітник II } \\
\hline 5 & \begin{tabular}{|l} 
Дзвіночок Портен- \\
шлага
\end{tabular} & $\begin{array}{l}\text { Campanula po } \\
\text { Schult. }\end{array}$ & 75 \\
\hline 6 & $\begin{array}{l}\text { Хоста подорожни- } \\
\text { кова }\end{array}$ & Hosta plantaginea (Lam.) Asch. & 50 \\
\hline \multicolumn{4}{|c|}{ Квітник III } \\
\hline 7 & Лілійник сортовий & Hemerocallis L. & 20 \\
\hline 8 & Тюльпан гібридний & Tulipa $\times$ hibrida & 40 \\
\hline \multicolumn{4}{|c|}{ Квітник IV } \\
\hline 9 & $\begin{array}{l}\text { Вербозілля крап- } \\
\text { часте }\end{array}$ & Lysimachia punctata L. & 25 \\
\hline 10 & Шафран посівний & Crocus sativus L. & 25 \\
\hline \multicolumn{4}{|c|}{ Квітник V } \\
\hline & ерань гімалайська & Geranium himalayense Klotzsch & 80 \\
\hline
\end{tabular}

Схему розміщення рослин одного з квітників, а саме під номером I, показано на рис. 4.

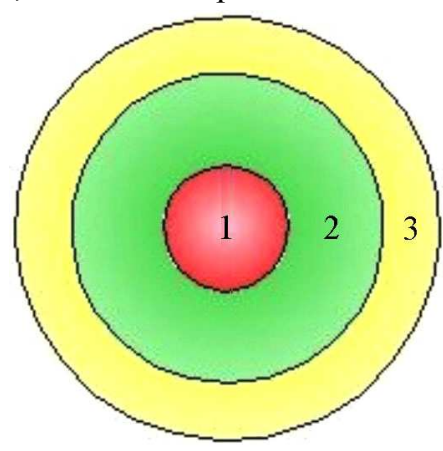

Рис. 4. Квітник I: 1) хоста подорожниколиста (Hosta plantaginea (Lam.) Asch.); 2) хоста гібридна (Hosta hybrida var. Altanis); 3) хоста ланцетолиста (Hosta lancifolia (Thunb.) Engl.); 1-3) нарцис білий (Narcissus poeticus L.)

Після виконаних робіт баланс території зазнає певних змін. На діаграмі (рис. 5) зазначено баланс наявної території (Kodzhebash \& Kodzhebash, 2018) та після реконструкції.

3 рис. 5 видно, що в парку збільшилася до оптимальної кількість доріжок із твердим покриттям завдяки зеленим насадженням, площа яких залишається найбіль- шою. Варто зазначити, що в парку площа квітників зросла на $47,25 \mathrm{~m}^{2}$.

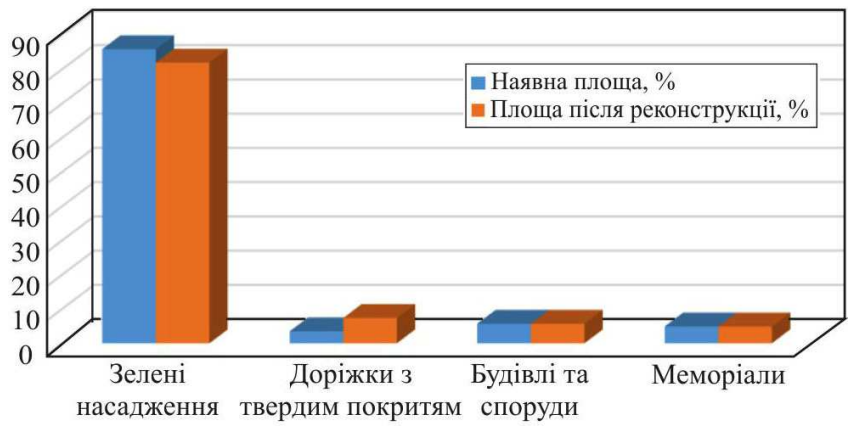

Рис. 5. Баланс території парку до і після реконструкції

\section{Висновки:}

1. Парк потребує санітарного рубання та обрізування дерев.

2. Рекомендовано створити мавританський газон, до складу якого входять: костриця червона (Festuca rubra L.), райграс пасовищний (Lolium perenne L.), тонконіг лучний (Poa pratensis L.), мак польовий (Papaver rhoeas L.), льон великоквіковий (Linum grandiflorum Desf.), ромашка лікарська (Matricaria recutita L.), низькорослі сорти космеї (Cosmos Cav.), чорнобривці мексиканські (Tagetes tenuifolia Cav.), гіпсофіла повзуча (Gypsophila muralis L.), гіпсофіла витончена (Gypsophila elegans M. Bieb.).

3. Запропоновано збільшити площу стежкової мережі на $347 \mathrm{~m}^{2}$, створивши доріжки з бетонної тротуарної плитки завширшки 0,75 та 1,5 м.

4. Заплановано встановлення альтанки, лавки та урни для сміття.

5. Позаду кругової лавки, у північно-східній частині парку, запроектовано створення декоративної групи 3 кущів (Berberis thunbergii DC, Forsythia europaea Deg. et Bald., Pyracantha coccinea (L.) M. Roem, Syringa vulgaris L., Cotoneaster horizontalis Decne.)

6. Заплановано створити нові квітники площею 47,25 м² 3 використанням таких рослин: Hosta plantaginea (Lam.) Asch., H. hybrida var. Altanis, H. lancifolia (Thunb.) Engl., Narcissus poeticus L., Campanula portenschlagiana Schult., Hemerocallis L., Tulipa $\times$ hibrida, Lysimachia punctata L., Crocus sativus L., Geranium himalayense Klotzsch.

\section{Перелік використаних джерел}

Dobrochaeva, D. N., Kotov, M. I., Prikudin, Iu. N., et al., (1987). Oprededlitel vysshikh rastenii Ukrainy. (1st ed.). Kyiv: Naukova dumka, 548 p. [In Russian].

Kodzhebash, A. V., \& Kodzhebash, A. P. (2018). Suchasnyi stan parku s. Pikivets Introduktsiia roslyn na Volyno-Podilli. Nauka, osvita, mystetstvo formuvannia landshaftu, vyrobnytstvo: materialy mizhnarodnoi naukovo-praktychnoi konferentsii, 17-18 travnia, (pp. 65-67). Ternopil. [In Ukrainian].

USDA. (2019). The Plant Database. Natural Resources Conservation Service. Retrieved from: https://plants.usda.gov/java/index.jsp.

Zaiachuk, V. Ya. (2008). Dendrolohiia: pidruchnyk dlia stud. VNZ. Lviv: Apriori, 410 p. [In Ukrainian]. 
A. V. Kodzhebash

Uman National University of Horticulture, Uman, Ukraine

\section{RECONSTRUCTION PROPOSALS FOR THE VILLAGE PARK PIKOVETS, UMAN DISTRICT}

Park in the village Pikovets, Uman District of Cherkasy Region was laid in the 1950-1960's in the centre of the village, namely the village club. First of all, it is necessary to carry out sanitary felling and pruning of trees. We suggest to sow the Moorish lawn and to replace the grass creeper (Elytrigia repens L.) in the place where the grass creep grows (Elytrigia repens L.) completely replace the grass with a lawn. According to the project, the tropical network is expanding. After the reconstruction, the area of the tracks will be $7.4 \%$. It is proposed to create paths from concrete pavement tile width of $0.75 \mathrm{~m}$ and $1.5 \mathrm{~m}$. Some paths serve a transit role, and some connect individual elements of the park. With small architectural forms in the park we establish a garden arbour for relaxation. We also propose to increase the number of benches by adding an arched bench on the circular platform where the flowerbed will be placed. Behind the circular bench, in the northeast part of the park, the creation of a decorative group of shrubs is projected. The plant range for this group includes as follows: Berberis thunbergii DC, Forsythia europaea Deg. et Bald., Pyracantha coccinea (L.) M. Roem, Syringa vulgaris L., Cotoneaster horizontalis Decne. For flower beds we use bulbous early flowering species, as well as mostly shade-bearing perennials. The range of plants for flower beds is as follows: hosta plantaginea (Hosta plantaginea (Lam.) Asch.), hosta hybrid (H. hybrida var. Altanis), hosta lanceolifolia (H. lancifolia (Thunb.) Engl.), poet's narcissus (Narcissus poeticus L.), portenschlagiana bellflower (Campanula portenschlagiana Schult.), daylily (Hemerocallis L.), hybrid tulip $($ Tulipa $\times$ hybrid), large yellow loosestrife (Lysimachia punctata L.), sativus crocus (Crocus sativus L.), Geranium geranium (Geranium himalayense Klotzsch). We recommend to create a Moorish lawn, which includes red oatmeal (Festuca rubra L.), pasture ryegrass (Lolium perenne L.), grassland meadow (Poa pratensis L.), field poppy (Papaver rhoeas L.), big flax (Linum grandiflorum Desf.), medicinal chamomile (Matricaria recutita L.), undersized cosmos (Cosmos Cav.), tagetes tenuifolia (Tagetes tenuifolia Cav.).

Keywords: lawn; flowerbed; sanitary pruning; stitch network; gazebo. 